\title{
THE BEST MAN IN THE PLAY: FEMALE AGENCY IN A GENDER-INCLUSIVE COMEDIA
}

\author{
ROBERT BAYLISS \\ University of Kansas
}

The critical landscape of Comedia studies has been reconfigured in recent years by the recovery and dissemination of plays written by women, and it continues to evolve and revise itself in what we may call the post-dramaturga age. Women-authored dramas are now out of the closet in our field, even though evidence is often scarce as to their public or private reception in the seventeenth century. The works of dramaturgas reflect and refract the "Golden Age" itself in new ways for us, shedding new light on this construct of literary historiography and the male playwrights who dominate its canon. Critics who first brought these alternative early modern voices to our attention were essentially feminist, insofar as they primarily focused on the feminine authorship of such plays as a distinguishing feature, promoting a critical practice of reading women-authored plays as a departure or deviation from the patriarchal norm; this tendency continues in current practice. ${ }^{l}$ While still recognizing the alterity of the dramaturgas as a vital element of their work's ideological dynamics, it is possible to critically engage their texts vis-à-vis the male canon in a way that does not stop with establishing their difference. With a focus on the dramatic convention of the cross-dressed woman, in this study I will advocate a reconsideration of the critical function of these women writers, who were undeniably marginalized in seventeenth-century society and in literary history until the very end of the twentieth century, in the now gender-inclusive field of Comedia scholar- 
ship. By redressing the convention of transvestism, the dramaturgas call into question the use of this convention by their male counterparts, but they also challenge our own critical tradition of reading the practice by male playwrights as a subversive promotion of "female agency" or even "feminism."

I place quotation marks around the terms "female agency" and "feminism" above because the dramaturgas make their use by Comedia critics since the 1970s fundamentally problematic. Ever since Melveena McKendrick's Women and Society in the Spanish Golden Age Theater (1974), Frederick A. de Armas's The Invisible Mistress: Aspects of Feminism and Fantasy in the Golden Age (1976), and Bruce Wardropper's seminal article, "La comedia española en el Siglo de Oro" (1978), popular urban comedy of the Spanish Golden Age (most often categorized as either capa y espada plays or comedias de enredo) have attracted critics because of how they privilege female characters. As the principal agents in determining the outcome of a standard and often formulaic amorous intrigue, women are represented as resourceful and clever subjects responding to the patriarchal constraints of honor and paternally arranged marriage. For their individual desires to be realized, especially in terms of to whom they shall be wed, these female protagonists must subvert societal constraints that would keep them enclosed and silenced.

It is not surprising that in today's critical climate, which privileges traditionally marginalized voices and counts feminism among its most prominent ideological perspectives, the popular success of this mode of popular comedy in the misogynist ideological climate of the Counter Reformation would be of interest to so many critics. The actions of these plays' female protagonists, after all, seem to openly defy prescriptions for female behavior as codified by humanists like Fray Luis de León and Juan Luis Vives. With the rise to prominence of the New Historicism, this interest has taken on renewed vigor; thanks to the exhaustive research that has yielded such studies as Thomas A. O'Connor's Love in the 'Corral', we now understand that the public performance of these plays was both immensely popular and institutionally problematic. In representing a female character whose individual autonomy is exercised to circumvent institutional, familial, and cultural (patriarchal) authority, these plays were considered dangerous models of behavior for the non-discerning paying public.

By grounding our studies of popular Spanish comedy in such concerns, 
we implicitly posit the following questions: Do these plays constitute a proto-feminist critique of early modern Spanish society? Can we ascribe to such prominent and canonical male writers as Lope de Vega (La dama boba $)^{2}$ and Calderón (La dama duende) ${ }^{3}$ some kind of early modern "feminism"? By placing such ostensibly "feminist" or "pro-woman" plays in dialogue with the work of female dramatists of the period we may explicitly treat these normally implicit questions. I will focus on the specific case of Ana Caro's Valor, agravio y mujer as a point of contrast to such plays as Tirso's Don Gil de las calzas verdes, but only as a concrete example of a wider trend: while the handful of now-published women dramatists of the period are understandably drawn to the popular forms of comedy described above, their work does not merely constitute a mechanical repetition of established conventions. Instead, they alter the circumstances, dynamics, and interpersonal conflicts of the popular maleauthored model in a way that suggests a dissatisfaction with what is supposedly a proto-feminist mode of comedy. In short, what women dramatists tell us is that the alleged "feminism" of Tirso and his male contemporaries deserves the same degree of feminist critique and scrutiny as any other work in the patriarchal canon.

\section{Women in the Golden Age}

In 1977 Joan Kelly asked a seminal question: "Did women have a Renaissance?" The rhetorical function of this speech act implies the critical stance assumed by Kelly and other feminist literary and cultural historians of the 1970s and 1980s: a questioning of the master narratives of European cultural history that our academic institutions and disciplines had constructed over the course of decades and even centuries. This revisionism has obviously changed the way we understand such constructions as the Spanish Golden Age, for we now know that underlying the story of cultural evolution in the West, from the "dark" Middle Ages to the early modern period of "rebirth" on the road to an eighteenth-century "Enlightenment," there is a lesser-told history of female subjugation, objectification, and containment-an alternate history that challenges the lens of "progress" through which the phalogocentric history of ideas has been read. What may be considered a progressive evolution of patriarchal institutions and societies - a more or less linear trajectory of history-is, especially prior to the nineteenth-century, starkly contrasted by a more cyclical and often repeating herstory. 
I raise Joan Kelly's question because it still resonates within the critical dynamics of Comedia studies, in which plays featuring subversive female protagonists, written by both men and women, attract more than their fair share of critical attention. Narrowing the focus, we may ask: did seventeenth-century Spanish women have a "Golden Age"? Of course the question has to be qualified, because the answer would depend on one's source, be it patriarchally institutionalized history or feminist revisionist history ("herstory"), or a play by a dramaturgo or a dramaturga. It now seems reasonable to presume that the gender of the author, the gendered authorial perspective, will inflect the portrayal of the dama onstage. Scholars working with women playwrights have thoroughly established this fact, to the point that one would be hard-pressed to find many scholarly publications dedicated to one or more of them in which gender did not weigh in heavily on the arguments put forth. We should take it as a lesson learned from our dramaturgas, then, that the male gender will likewise inflect his rendering of the dama-a point which may seem obvious to many, but which also appears to contradict a tradition of reading maleauthored popular comedy as subversively sympathetic to the plight of women in early modern society. Given the fairly recent arrival of female voices to the canon of Comedia studies, male-authored popular comedy was generally compared to other contemporary dramatic modes, such as the honor plays. It is understandable that, by comparison, the capa y espa$d a$ plays seemed to champion women's freedom, autonomy, and agency.

If the Comedia canon was once an exclusive club "for boys only," it has since gone co-ed. We should note the 1990 s as a pivotal period in this process, with the publication of several anthologies of early modern Spanish women's writing, including Teresa Soufas's Women's Acts, Julián Olivares and Elizabeth Boyce's Tras el espejo la musa escribe, and Amy Katz Kaminsky's Water Lilies. The recovery, dissemination, and promotion of the period's dramaturgas has opened new possible avenues of inquiry for the broader field of Comedia studies, but it also signals a need to revisit and revise earlier arguments made in the 1970s and 1980s about male-authored comedy, insofar as they are arguments that still resonate in the field today.

Like any scholarly publication, Frederick de Armas's The Invisible Mistress reflects the critical climate in which it was written: drawing upon the analytical models of Structuralism and Archetypal Criticism (Northrop Frye in particular), de Armas traces the diachronic evolution of 
a trope that began in classical antiquity and, after filtering through various generic frameworks, eventually yielded such comedias as Lope's $L a$ viuda valenciana and Calderón's La dama duende. These plays, argues de Armas, share a common "deep structure" with Romance (in Frye's sense of the term $)^{4}$ whose defense of women or "feminism" counterbalances the more ideologically dominant misogyny of the Western canon. What might appear most striking about the book to today's Comedia scholar is its conflation of women writers and male-authored representations of women. ${ }^{5}$ This conflation makes sense given that The Invisible Mistress predates the arrival of "gynocritical" feminist theory to Hispanism, but it is important nonetheless: Zayas (as novelista) and Calderón share a pattern of portraying women that is pro-woman:

This essential ambiguity in the portrayal of women will become particularly striking in Golden Age versions of the Invisible Mistress plot. Although comedias and novelas will contain certain misogynistic traits, their feminism will somehow emerge through or in spite of role reversal. (17)

The point here is not to evaluate the currency of The Invisible Mistress thirty years after its publication, but rather to trace the roots of a tendency in Comedia scholarship to embrace popular comedias as "womanfriendly." It is a view of male-authored texts that originated before the dramaturgas were recovered from the margins of patriarchal canonicity, but which now (in what I am calling the "post-dramaturga age") maintains a tenuous residual presence in our critical perspectives. ${ }^{6}$ De Armas's book and Melveena McKendrick's Woman and Society in the Spanish Drama of the Golden Age (1974) mark the origins of this focus on works in which women characters are given center stage. These studies proved so influential that the mujer varonil, in particular the mujer vestida de hombre variety, is even more fascinating to critics today, with the insights that have been gained from the integration of psychoanalytical, gender, and feminist theories into our critical repertoires. At the time, however, feminist critical voices along the lines of Eve Sedgewick, Judith Butler, and Joan Kelly were only beginning to emerge, and were not yet directly impacting Comedia scholarship.

A year after Joan Kelly's seminal essay and title-question was published, Bruce Wardropper published an appendix to a Spanish translation 
of Elsen Older's book Theory of Comedy, an essay titled "La comedia española del Siglo de Oro." In it he notes the scarce attention paid until then to comic plays that are by nature not as "serious" as the plays that had to that point received the lion's share of critical attention; he classifies such works under the rubric of comedias de capa y espada. The liberal humanism that had characterized much of twentieth-century Comedia criticism to that point, dominated by the critical approach of North American New Criticism and Structuralism, slighted the stylized and formulaic comedias ligeras for what were then perceived as more philosophically substantive obras maestras: the honor plays and other works such as La vida es sueño, Fuenteovejuna, and El burlador de Sevilla. ${ }^{7}$ In 1978, Wardropper quite perceptively sensed a sea change in the field, at least in part inspired by the McKendrick and de Armas's books, and even a cursory glance through recent issues of this journal validates his claims that works like Lope's La dama boba, Tirso's El castigo del penseque, and Calderón's La dama duende are squarely centered on our critical radar.

I find the rough contemporaneity of the Kelly and Wardropper essays and de Armas's book indicative of a major reason why Comedia scholars first became interested in popular comedy: as feminism began to infiltrate another "boys' club," the twentieth-century academy, these comedias ligeras were read as sympathetic to women, as dramatizations of the dama's struggle for autonomy and self-determination in the face of intensely patriarchal and misogynistic cultural and institutional circumstances. We may now have other, more theoretically current interests in the comedias de capa y espada, such as the fact that these were the mainstay of the popular theater industry, and the most frequent objects of moralist critique and institutional censorship, but in 1978 Wardropper's interest hinged on the notion that these plays "nos muestra el triunfo de las mujeres sobre los hombres" (221). Eager to adjust Comedia studies to a newly refashioned critical and political landscape sympathetic to late twentieth-century feminism, these plays constituted for Wardropper a reversal of the real-world social order, in which "se puede poner el mundo patas arriba; el esclavo puede esclavizar al esclavizador" (222); they were a recognition of the universal truth that "[I]a sociedad es enemiga de los derechos de las mujeres, que deben aprender a manipular el sistema masculino si es que han de llevar en él una vida soportable" (225). In a word, these plays are 
subversive, but in a way that was often read in the context of a battle between the sexes.

\section{Men Dressing Women as Men}

I consider Tirso de Molina's Don Gil de las calzas verdes representative of this subversive mode of comedy, and a play that lends itself quite easily to a "Wardropperian," arguably "feminist" but certainly "prowoman" reading. In keeping with the standard capa y espada plot circumstances, a series of male initiatives has made it necessary for the dama to subversively take matters into her own hands in order to enter the state of matrimony on her own terms. In this case, a series of male blunders forces Juana to assume male garb to restore her honor and hold her galán to his word. After promising marriage, Martín has loved her and left her to wed Inés, the daughter of a wealthy old friend of his father. Based on the tried and true formulae of economic class warfare, intergenerational conflict, and the battle between the sexes, Tirso's arrangement neatly places Juana in the position of the powerless and disenfranchised.

The fact that Martín's good name has been tainted by his social obligation to Juana leads his father to invent for him a false identity, a proxy named Don Gil de Albornoz, as he heads from Valladolid to Madrid to meet his future bride. As a prototypical dama of a capa y espada comedy, Juana refuses the passive role of dishonored victim and relies upon her wits to repair her lost honor, whether by forcing Martín's hand and wedding him or by killing him. Her plan for intervening and disrupting Martín's newly arranged marriage involves assuming this same identity of Don Gil. In the course of the plot's dizzying machinations, the fact that Don Gil doesn't really exist allows everyone else to compete for his identity as the ideal male suitor: at one point four Don Giles are onstage at the same time. Of course Juana wins the competition: her incarnation of Don Gil, el de las calzas verdes, upstages Martín and steals the prize of Inés's affection, along with the heart of her cousin Clara as collateral damage. In Tirso's carnavalesque enredo, Juana is in fact the best man in the play.

As this initial reading of Tirso's play suggests, many aspects of the predramaturga mode of analysis still resonate today, such as Wardropper's notion of a dramatic world in popular comedy that inverts the social order of the real world, el mundo al revés, and the observation that the leading women of these plays "saben ver con mayor claridad lacras sociales a las 
que los hombres parecen ciegos" (226); or that "[l]as mujeres de la comedia no solo actúan con mayor ingenio que los más de los hombres" (226), a point well substantiated by Don Gil de las calzas verdes. Since the recovery of our dramaturgas, however, other suppositions seem more problematic, in particular the following statement: "Aunque escrita por hombres, la comedia adopta un punto de vista femenino" (226). In the pre-dramaturga era of Comedia scholarship, this judgment made sense, for in the absence of a woman's voice, in the absence of women representing women, those damas crafted by male dramatists seemed somehow feminist in their words and deeds. To be sure, in Don Gil Tirso employs Juana as a surgeon would a scalpel, to cut through standard social practices and expose the hypocrisy of men behaving badly. But assigning a "punto de vista femenino" to Tirso, as if he were "getting in touch with his feminine side," is to suggest that there is no substantive difference between the perspective of male and female writers, at least within the generic realm of the comedias de capa y espada. Revisiting a text such as Ana Caro's Valor, agravio y mujer will allow us to test the validity of such a suggestion.

\section{Women (Re)Dressing the Cross-Dressed Woman}

We can question the validity of Wardropper's assertions today because we are now reading and witnessing performances of plays written by women-plays that undermine any claims of male dramatists sharing a "feminine point of view." Considering such "pro-woman" readings of male-authored popular comedias in light of what we have learned from their female contemporaries leads me to ask: if a feminine point of view was already being offered in the corral by the dramaturgos, why would women dramatists feel the need to revisit this genre? Why not challenge the more overtly misogynistic generic field of tragedy or the honor plays, for example? And yet when we look at the extant plays written by women in the period, we see a broad range of genres covered, but with a noteworthy concentration of plays written in this same mode of popular comedy in which the dama reigns supreme. In the Soufas anthology Women's Acts, for example, five out of eight plays share close generic ties with Don Gil.

While the dramaturgas' sympathies with such modes of comedy are understandable, their work does not merely constitute a mechanical repetition of established male-authored conventions. In other words, their 
attraction to the capa y espada mold does not lie in its merely being a generic safe-haven for female agency and wit, or the dramatic equivalent to the shallow end of the swimming pool; the dramaturgas engage this generic space critically, and in a way that we must now reconcile with standard readings of the genre as practiced by the male-authored canon. This has been demonstrated ably by such scholars as Amy Williamsen, Gwyn Campbell, and Teresa Soufas, to name only three of the many scholars who, primarily in the 1990 s, focused on the ways in which seventeenth-century women dramatists challenged the status quo, often by working from within standard dramatic conventions. It is noteworthy, for example, that María de Zayas's only extant play, La traición en la amis$t a d$, is in many ways a traditional comedia de enredo. Although the particulars are tweaked in a way that challenges the male formula's treatment of women, an argument ably made by Campbell in terms of the distinction between sex and gender, we know from her prose fiction that Zayas's imagination was capable of far more blatant forms of critique, including striking instances of violence. As Barbara Mujica and Amy Williamsen have shown of Valor, agravio y mujer and as Lola Luna has shown of $E l$ conde Partinuplés, Ana Caro reworks male-authored fictional paradigms in a way that similarly questions their implicit misogyny, much as Sharon Voros has convincingly shown of Leonor de la Cueva. More recently, Christopher Gascón and Darlene Múzquiz-Guerreiro have shown us the extent to which Ângela de Azevedo's El muerto disimulado performs a similar critique from within the standard conventions of popular comedy. What these scholars collectively suggest is, again, that the alleged "feminism" of Lope and his male contemporaries is problematic in a genderinclusive Comedia canon.

We may consider Ana Caro's Valor, agravio y mujer as exemplary of this proto-feminist revision. The plot is in many ways parallel to that of Tirso's Don Gil: Leonor has surrendered her virginity and honor to an ingenuous Don Juan, only to be abandoned by him as he seeks greener pastures, in this case the princess Estela. Like Tirso's Juana, Leonor assumes a fictional male identity in order to disrupt and thwart her lover's marriage aspirations, and like Juana she captures the heart of her unwitting rival. Both in her (apparently) homosocial dealings with the other men of the court and in superiority as object of female desire, then, Leonor also shares with Tirso's protagonist the ironic role of "best man in the play." As Soufas has shown ("Ana Caro's Re-evaluation" 87), the 
assumption of male identity and dress involves a temporary suspension of femininity itself; it is in the details of this suspension, in particular its implications for how the protagonist treats other women, that a divergence of gendered authorial perspectives between Tirso and Caro may be perceived.

A key point of contrast between the two plays lies in the seduction of the rich female rival by the cross-dressed woman. Both Caro and Tirso base their respective enredos on impeding the wedding of the mujer varonil's would-be lover to another by distracting this "other woman" with a more palatable option; but whereas Tirso's Juana achieves this important part of her strategy effortlessly, through a love-at-first-sight public encounter with Inés, Caro's Leonor participates in the charade with far greater ambivalence. Her first on-stage exchange with Estela is in fact prompted by the princess's chastising of "Leonardo" for not speaking to her: " $\mathrm{OO}$, qué mal cumplís, qué mal, / la ley de cortesía, / la obligación de galán!" (174). ${ }^{8}$ Leonor /Leonardo's eighty-line response invokes the typical comedia performance of male courtly desire, ironically commented upon by her servant Ribete for its poetic eloquence, but Estela dismisses it as empty rhetoric pronounced "por querer cantar" (175). Leonor /Leonardo does procure an evening rendezvous with Estela after further gesticulation (to which Estela replies, " $i Q u e ́$ bien sabes persuadir!"), which provides the opportunity to further her enredo by having Juan's rival Ludovico go in "his" place. In terms of the discursive dynamics of the play's representation of "the battle of the sexes," this exchange sets the scene for a more telling dialogue in the third act of the play.

As the prize sought by various male suitors in the play, Estela is familiar with typical male strategies of seduction. Both the prince Ludovico and the noble and heroic Don Juan (the play opens with his rescue of Estela and Lisarda from a group of bandoleros) employ the same rhetorical strategies of courtly love as those that Estela had dismissed when practiced by Leonor/Leonardo. Their running complaints of her disdain for them, however, reveal the fundamentally egoistic and self-absorbed nature of this courtly discourse. Ludovico's complaint in Act 2, for example, focuses on the damage to his ego done by her rejection of his advances: "desaire que me ha enfadado, / por ser tan pública ya / mi pretensión" (176). In an earlier conversation with Fernando, he elaborates on his claims to deserve Estela's hand: 
LUDOVICO. ¿Puede aspirar

Estela a mayor altura?

Su riqueza, su hermosura, ¿en quién la puede emplear como en mí?

FERNANDO. Decís muy bien.

LUDOVICO. ¿Hay en todo Flandes hombre más galán, más gentilhombre? (170)

Whereas Ludovico and Juan feel that they deserve Estela as a prize for their own intrinsic worth and social standing, Leonor/Leonardo assumes a different rhetorical posture in the final act of the play, one that reflects her ambivalence about manipulating the heart and desires of another woman who, after all, faces the same disingenuous male advances as those that have left Leonor in her current predicament. Leonor/Leonardo's lack of presumption stands in stark contrast to the pride of her rivals: "Como no está el merecer / de mi parte, sé querer, / pero no satisfacerme"; "No hay en mí satisfacción / de que me puedas amar / si mis partes considero" (186). Estela is quick to dismiss such statements as "injusta desconfianza" as she invites Leonardo to another private meeting. On one level, Leonor invokes the "rhetoric of humility" that has been identified as a rhetorical device of other early modern women writers like Teresa de Ávila, and Estela's choice of Leonardo over "his" rivals seems to reward such a tactic. Leonor's musings after Estela exits the stage, however, suggest that her "desconfianza" is not simply rhetorical, but rather a reflection of her own misgivings about how she has manipulated the princess:

En males tan declarados, en daños tan descubiertos, los peligros hallo ciertos, los remedios ignorados; no sé por donde jay de mí! acabar; amor intenta la tragedia de mi afrenta. (186)

Leonor's awareness of her own hypocrisy therefore conditions the terms on which "he" courts Estela. Unaware of this internal conflict, Estela simply notes that Leonardo is not like her other suitors, and she 
finds that difference attractive. In a manner that may appear perfunctory, as comedia conclusions often do, the now publicly female Leonor makes peace with her newly betrothed sister-in-law:

ESTELA. Leonardo, ¿así me engañabas?

LEONOR. Fue fuerza, Estela.

ESTELA.

Quedemos

hermanas, Leonor Hermosa;

Fernando, ¿de esposo y dueño

me dad la mano? (194)

We will see that even this cursory peacemaking departs from Tirso's final scene in Don Gil; the point here is that for Ana Caro, recognition and closure require that she resolve the tension created by Leonor's manipulation of another woman. Perhaps it is not the focus of the play as it is in Zayas's La traición en la amistad, but female friendship and solidarity is nonetheless an important component of the values promoted by Caro in this play. All of this validates a claim made by Soufas:

In Golden Age male-authored plays, the female character frequently is portrayed as being "as good as a man" for a period when she must struggle against injustice so that she can settle back into the passive status of wife, usually of the very man who has mistreated her earlier. Caro suggests an alternative to this patriarchal evaluation because her female character disguised as a man does not conduct herself as do the typical males. She is a "better" (hu)man in the moral sense and enacts a more just and moral response to the question of male attitudes toward a woman deceived by an unfaithful man. (88-89)

Thus, while Tirso's Juana and Caro's Leonor are "the best men" of their respective plays, it is the latter's concern for the moral dimension of this value, the privileging of friendship and solidarity over egotism and ambition, that suggests an exemplary function to the mujer varonil that I find lacking in Don Gil. Comparing the two plays along these lines suggests the ways in which our "post-dramaturga" readings of the male-authored canon might challenge previous assumptions about it. 


\section{Comparative Transvestisms}

Christopher Weimer and Beatriz Cortez are among those scholars who are now taking the study of early modern dramaturgas one step further, into a dialogue with the male canon. By offering comparative readings of La vida es sueño and a comedia by Ana Caro (El conde Partinuplés in Weimer's study and Valor, agravio y mujer in Cortez's article), both scholars show us the potential of this method to more clearly establish the literary, theatrical, and ideological relationships between our dramaturgos and dramaturgas. For Weimer, intertextuality provides a concrete link between Caro and Calderón, thus leaving little doubt that the former had in mind the model of the latter, with all of the cultural authority his name implied, as she wrote her play in the mode of "heuristic imitation." Weimer borrows the term from Thomas Greene and finds it useful for establishing an intertextual relationship that still allows for "distance" between the two works, in other words, a space in which Caro can revise and resubmit the male-authored model. Cortez, on the other hand, focuses on the theatrical convention of the cross-dressing woman to reveal how divergent its employment is in Calderón and Caro. While Calderón's Rosaura resorts to transvestism in a way that can be (and has been) read as proto-feminist, Cortez notes that her role becomes increasingly peripheral to the play's action; Caro's Leonor instead denaturalizes "el binarismo del género" on the way to offering a model of feminine agency. In both comparisons, the patriarchal intertext is met with a proto-feminist revisionary agenda.

For me, the most important contribution of these studies is methodological. Comparative readings of male and female dramatists of the Spanish baroque provide a framework in which the wide array of theoretical approaches at our disposal today may be brought to bear on the dynamic relationship between the public spectacles authored by men and that which we may call escritura femenina, whether produced and performed publicly or not. While it is difficult to imagine such a comparison being made without some reference to feminist theory, we know that our current theoretical buffet allows for such a framework to be combined with others-be they neo-historical, psychoanalytical, Marxist, Queer, or what have you. The particulars of any given play or of any two plays placed in dialogue with one another will lend themselves to different methods and perspectives. Where La vida es sueño allows Cortez to establish a contrast in terms of feminine agency, I see merit in bringing 
Valor, agravio y mujer into dialogue with male-authored plays that do not marginalize the cross-dressing woman, plays in which she does remain the focus of dramatic attention from beginning to end-plays that, like Don Gil de las calzas verdes, had been read in the pre-dramaturga era as pro-woman or even feminist. In other words, Weimer and Ortiz have shown how the obras maestras privileged by A. A. Parker and those influenced by the New Critics are ripe for feminist revision; but what of the ostensibly female-friendly, "less serious" plays embraced by de Armas and Wardropper at the end of the 1970s. Such a dialogue would bring into sharp relief that which has been considered a pro-woman stance in maleauthored popular comedies. It is my contention that our readings of representations of women authored by men must adjust to the new perspective that such a dialogic and comparative method would bring.

\section{Revisiting the Male Canon}

Turning to what Caro's play may teach us about Don Gil, we may say that both plays are meant to indict problematic patterns of male behavior. I have already suggested that Tirso's Juana serves a satirical purpose, but what Caro's example suggests is that the mujer varonil may also posit a positive example of female behavior, and that such an example takes into account the same issues of female solidarity and friendship that are the focus of other female-authored plays like Zayas's La traición en la amis$\mathrm{tad}$. While both protagonists must temporarily put aside their femininity to step into the public sphere of male action, we have seen that Caro's Leonor finds the endeavor morally problematic, insofar as being varonil involves manipulating other women and courting them under false pretenses.

Tirso's Juana experiences no such crisis of conscience-a fact that reflects how little responsibility she feels for the defense of her gender. Whereas Caro's critique focuses squarely on her play's male characters, in Tirso there is plenty of blame to share among both sexes. Inés is a fickle woman who falls desperately in love with Juana/Gil only moments after promising her suitor Don Juan that he has nothing to fear, that she is firmly committed to him. She later proves capable of behavior that is every bit as morally bankrupt as that of any man: she manipulates the jealous Don Juan into promising to kill another Don Gil (Martín, Juana's runaway husband) so that he will no longer be in the way of her plans to marry Juana/Gil. Inés's lack of scruples and her inconstancy would 
appear to confirm the worst of the period's misogynist cultural assumptions about the weaker sex. We might even suspect that a degree of narcissism is at the bottom of Inés's attraction to Juana/Gil, the one object of desire to whom Inés remains constant: "his" very effeminacy sets him apart from other men. When Martín claims the same name, she is quick to clarify that his physical appearance does not match that of the newly discovered love-of-her-life: "¿Don Gil tan lleno de barbas?/ Es el Don Gil que yo adoro / un Gilito de esmeraldas" (159). Inés will later explain to Juana, who this time has assumed the identity of a woman named Elvira, that "Causa suelen decir que es / del amor la semejanza" (267). Rather than by a bond of solidarity, then, femininity is characterized by narcissistic desire, inconstancy, and jealousy.

If this play is no longer assumed to be a defense of women, then it should come as no surprise that Juana does not defend her sex. Her indifference towards Inés as she manipulates her stands in stark contrast to Caro's play: at the conclusion of Don Gil, Juana reveals her identity to Martín and accepts his hand but says nothing to Inés, who in turn speaks only to Don Juan about their own marriage. While Caro's recognition scene offers a brief exchange so as to restore harmony between the women, Tirso makes no such effort-a point that underscores the playwright's lack of interest in female homosocial bonds. At an earlier point in the play, Juana offers the following telling aparte after Inés exits the stage: "Ya esta boba está en la trampa. / Ya soy hombre, ya mujer, / ya don Gil, ya doña Elvira. / Mas si amo, ¿qué no seré?" (185). This selfabsorbed and egocentric disregard for any "collateral damage," such as the emotions of another woman, suggests that Juana's adoption of a masculine identity extends beyond clothing and into (moral) character.

Tirso's lack of concern for the figurona Inés and for her gender explains why Juana fails to respond to a number of overtly misogynist and homophobic comments made throughout the play. A running joke of the play consists of Caramanchel's off-the-cuff comments regarding his new master's effeminate qualities, which have been studied adeptly by Matthew Stroud through the lens of Lacanian theory. Caramanchel is aware of (if not obsessed with) the androgyny that attracts Inés to his master, even if Juana/Gil's jealous rivals are not, and his constant references to Don Gil as hermafrodita or capón exploit this physical quality of the cross-dressed woman for comic effect. Designating a man as effeminate or androgynous, we should recall, was a popular and devastating 
method of the early modern satirist. As Sidney Donnell has recently argued in his book Feminizing the Enemy, the notion of femininity was ideologically loaded in the seventeenth century. The decline of the Spanish Empire and the moral decadence of nascent urban culture were frequently addressed in terms that employed the feminine as a diagnostic tool. We only need recall Governor Arnold Schwarzenegger's recent claim that an ineffective California legislature consisted of "girly men" to recognize the residual presence of such misogyny in the twenty-first century. In the early modern era, then, it seems anachronistic to suggest that Tirso's mujer varonil is meant to make a positive statement about femininity.

By questioning the "pro-woman" reading of male-authored capa $y$ espada comedies I do not mean to suggest that Don Gil is not a subversive text; clearly some sort of subversion is going on, and the cross-dressing dama is undoubtedly integral to it. Since classical antiquity the trope of woman as "mirror" has existed, and I would posit that it takes on a satirical function in Tirso's play: the faults and problems that the patriarchy fails to recognize in itself are instead reflected by a woman dressed as a man. Juana is, after all, the best man in the play, but this may say more about the play's male characters than it does about her. Like Caro's Leonor, she is able to impress the play's other women, female objects of male desire, in a way that her male rivals are unable to reproduce. But unlike Caro's mujer varonil, Juana's sexual magnetism is not so much due to her ability to appeal to a "punto de vista femenino," as Wardropper would have it, as it is to the superficial, fickle, and narcissistic character of Inés. All the worse for the men who can do no better than dress in green in a vain attempt to approximate a scorned transvestite. Simply put, Tirso's use of woman is more utilitarian than feminist: Juana is an instrument, a didactic tool through which Tirso ridicules his fellow men (and women), all for purposes of entertaining a mixed-gender audience. In this sense Juana's function seems to echo that of Laurencia in Lope's Fuenteovejuna, who incites the hitherto impotent male citizenry to depose the Comendador with the threat that, in the absence of such a male initiative, the women will have do the men's work while the men remain at home with their needlework.

My reading of Don Gil as neither explicitly misogynist nor feminist is a result of my exposure to the marginalized voices of our dramaturgas. Dramas of Distinction, the companion piece to Soufas's anthology, is a 
landmark study that synthesizes much of what has been described above. In her opening chapter she points to a common thread running throughout the texts of the anthology: "What emerges from my reading of these plays as texts... is an encoded pattern of disruption for the ideological category 'Woman,' challenging the patriarchal insistence on the inherently natural quality of the two-gendered hierarchy that assigns women to enclosure and silence and men to public and vocal exercise of agency" (12). Consider this analysis in comparison to how Juana describes her decision to assume the identity of Don Gil: "Saqué fuerzas de flaqueza, dejé el temor femenil ..." (94). This cite echoes several moments in Don Gil in which Juana expresses an essentialist understanding of her own gender, even when speaking with Inés as Elvira. What Soufas has identified as a distinguishing feature of an authentic female voice, an antiessentialist rejection of the ideological category "Woman," reveals the voice of Tirso's Juana for what it is: a male voice enunciated by a female actress, a kind of counter-cross-dressing that problematizes the convention of the woman dressed in male garb. In light of our dialogue with the dramaturgas, the notion of a mujer varonil takes on new layers of meaning.

Juana's subversive actions are not "feminine," not as Tirso and his contemporary educated men understood lo femenino. Rather, as quintessential mujer varonil, she suspends her gender identity until the final scene of anagnorisis, in which she returns to female dress and to her identity as female; we have seen that Caro's version of this transformation takes into account female homosocial relations of which Tirso appears to be unaware or at least uninterested. Like Leonor, Juana's assumption of male identity is made out of necessity, in the absence of her father and in response to her lover's failure to own up to his prior commitment to her. All ends well in Tirso's play because, despite her initial claims to seek revenge, what Juana really wants is to marry Martín, to be a wife, to assume her "natural" role as determined by the patriarchal institution of marriage. She will do anything (including temporarily being a man) to make it happen.

Some of this description may apply to the woman-authored Leonor as well, but a key difference is that Caro's mujer varonil accepts the hand of a reformed Don Juan. Leonor reveals her identity and returns to womanhood only after Don Juan, duped into believing that she now loves "Leonardo," affirms that he would "adore" her had she remained faithful 
to him. Her enredo, unlike that of Tirso's Juana, educates her would-be lover, shows him the error of his ways, and makes him realize a more idealized vision of love. The betrothal of the Don Gil protagonists, on the other hand, involves holding a man of questionable character accountable for his unfulfilled promises and obligations. Believing himself pursued by the ghost of Juana after she dies giving birth to his child, Martín faces Juana's father at the same time that his false identity is confirmed for Inés and her father. Thanks to their respective cross-dressed women, then, Caro's galain learns to be the best man in the play, while Tirso's galán is rescued by a dama-ex-machina.

This comparative reading suggests one of the challenges that early modern dramaturgas present to Comedia scholarship as it canonizes them: our prior assumptions about the male dramatists of the era must be revisited in light of this new data. A clear problem is the critical legacy of pre-dramaturga studies dedicated to the capa y espada plays, now that we have an authentic "punto de vista femenino" against which they may be measured. I would argue that the subversive nature of this genre is not divorced from questions of gender, particularly when the plot is driven by the machinations of a mujer vestida de hombre, but that the role of gender in this subversion needs to be reformulated. Herein lies the problem with pre-dramaturga readings of the capa $y$ espada plays: to read the disparity between the real-world oppression and enclosure of women and the mundo al revés of the Comedia as the championing of female autonomy and agency is to ascribe twentieth-century values to seventeenth-century culture. Such an anachronism may have seemed plausible when womanauthored plays were still consigned to the margins of patriarchal oblivion, but thankfully we now have nuestras queridas dramaturgas to set us straight.

\section{NOTES}

1. Among those most directly responsible for our canonization of the dramaturgas is Teresa Soufas, whose anthology Women's Acts remains a primary source for women-authored comedias; her Dramas of Distinction contributed to an emerging field of dramaturga scholarship that also included Barbara Mujica, Sharon Voros, Catherine Larson, Anita Stoll, Valerie Hegstrom, and Amy Williamsen. For examples of the continued critical focus on gender and authorship, see Christopher Gascón and 
Darlene Múzquiz-Guerrero's recent articles on Ângela de Azevedo in vol. 57.1 of this publication.

2. Examples of published studies of La dama boba that endorse a "feminist" interpretation include Mary Gaylord's "Las damas no desdigan su nombre" and David Gómez-Torres's "La dama boba de Lope de Vega o la subversión de un discurso monológico."

3. "Feminist" readings of La dama duende are numerous: see, for example, de Armas's The Invisible Mistress (123-60) and Barbara Mujica's Calderón's Characters; Mujica elaborates her argument with a focus on Calderón's La discreta enamorada in "Honor from the Comic Perspective."

4. See especially The Secular Scripture and The Anatomy of Criticism.

5. There is actually only one Spanish woman writer, Maria de Zayas, whose perspective is considered; the fact that Zayas's novelas were the only woman-authored texts on the critical radar (not even La traición en la amistad was widely available to scholars) indicates how much the canon has since changed. A glaring instance of this book's date is the fact that Ana Caro's El Conde Partinuplés was still unknown-a fact ironically highlighted by the importance ascribed by de Armas to the French romance Partonopeus de Blois in the transmission of the mythic trope of invisible mistress.

6. See, for example, Melveena McKendrick's 2004 article, "Breaking the Silence: Women and the Word in the Comedia."

7. It should be noted that most of these "great works" assign a more marginal role to women than do the cape and sword plays.

8. All citations of Caro's play are taken from the Soufas anthology Women's Acts.

\section{WORKS CITED}

Boyce, Elizabeth S., and Julian Olivares, eds. Tras el espejo la musa escribe: Lirica femenina de los Siglos de Oro. Mexico City: Siglo Veintiuno, 1993.

Cortez, Beatriz. "El travestismo de Rosaura en La vida es sueño y de Leonor en Valor, agravio y mujer: el surgimiento de la agencialidad femenina y la desnaturalización del binarismo del género." Bulletin of the Comediantes 50.2 (1998): 371-85.

de Armas, Frederick A. The Invisible Mistress: Aspects of Feminism and Fantasy in the Golden Age. Charlottesville, VA: Biblioteca Siglo de Oro, 1976.

Donnell, Sidney. Feminizing the Enemy: Imperial Spain, Transvestite Drama, and the Crisis of Masculinity. Lewisburg, PA: Bucknell UP, 2003.

Frye, Northrop. Anatomy of Criticism. Princeton: Princeton UP, 1957.

The Secular Scripture: A Study of the Structure of Romance. Cambridge: Harvard UP, 1976.

Gascón, Christopher. "Female and Male Mediation in the Plays of Ángela de Azevedo." Bulletin of the Comediantes 57.1 (2005): 125-45.

Gaylord, Mary. "'Las damas no desdigan de su nombre': decoro femenino y lenguaje en el Arte nuevo y La dama boba." Justina: Homenaje a Justina Ruiz de Conde en su ochenta cumpleaños. Ed. Elena Gascon-Vera. Erie: ALDEEU, 1992. 71-81. 
Gómez-Torres, David. "La dama boba de Lope de Vega: Un caso de subversión aparente o el proceso de formación de un discurso monológico." Bulletin of the Comediantes 48.2 (1996): 315 27.

Hegstrom, Valerie, and Amy R. Williamsen, eds. Engendering the Early Modern Stage: Women Playwrights in the Spanish Empire. New Orleans: UP of the South, 1999.

Kaminsky, Amy K. Water Lilies. Flores del agua. An Anthology of Spanish Women Writers from the Fifteenth through the Nineteenth Centuries. Minneapolis: U of Minnesota P, 1996.

Kelly, Joan. "Did Women Have a Renaissance?" Women, History, and Theory: The Essays of Joan Kelly. Chicago: U of Chicago P, 1984. 19-50.

Larson, Catherine. "Valor Judgments, or Women Writers and the Comedia." Brave New Words: Studies in Spanish Golden Age Literature. Ed. Edward Friedman and Catherine Larson. New Orleans: UP of the South, 1996. 259-70.

"You Can't Always Get What You Want: Gender, Voice, and Identity in Women-Authored Comedias." Gender, Identity, and Representation in Spain's Golden Age. Ed. Anita K. Stoll and Dawn L. Smith. Lewisburg: Bucknell UP, 2000. 127-41.

Luna, Lola. "Ana Caro, una escritora 'de oficio' del Siglo de Oro." Bulletin of Hispanic Studies 72.1 (1995): 11-26.

McKendrick, Melveena. "Breaking the Silence: Women and the Word in the Comedia." Revista Canadiense de Estudios Hispánicos 29.1 (2004): 13-30.

Women and Society in the Spanish Drama of the Golden Age: A Study of the Mujer Varonil. London: Cambridge UP, 1974.

Molina, Tirso de. Don Gil de las calzas verdes. Ed. Alonso Zamora Vicente. Madrid: Castalia, 1990. Mujica, Barbara. Calderón's Characters: An Existential Point of View. Barcelona: Puvill, 1980. . "Honor from the Comic Perspective: Calderon's Comedias de capa y espada." Bulletin of the Comediantes 38.1 (1986): 7-25.

"Women Directing Women: Ana Caro's Valor, agravio y mujer as Performance Text." Hegstrom and Williamsen 19-50.

Múzquiz-Guerrero, Darlene. "Symbolic Inversions in Ángela de Azevedo's El muerto disimulado." Bulletin of the Comediantes 57.1 (2005): 147-63.

O'Connor, Thomas. Love in the "Corral": Conjugal Spirituality and Antitheatrical Polemic in Early Modern Spain. New York: Peter Lang, 2000.

Soufas, Teresa. "Ana Caro's Re-evaluation of the Mujer varonil and Her Theatrics in Valor, agravio $y$ mujer." Stoll and Smith 85-106.

. Dramas of Distinction. Lexington: UP of Kentucky, 1997.

ed. Women's Acts. Lexington: UP of Kentucky, 1997.

Stoll, Anita K., and Dawn L. Smith, eds. The Perception of Women in Spanish Theater of the Golden Age. Lewisburg, PA, and London: Bucknell UP, 1991.

Stroud, Matthew. "'Y sois hombre o sois mujer?': Sex and Gender in Tirso's Don Gil de las calzas verdes." Stoll and Smith 67.82. 
Voros, Sharon. "Armesinda's Dream: Leonor de la Cueva's Challenge to the Patriarchy in La firmeza en la ausencia." Revista Monográfica 13 (1997): 74-86.

Wardropper, Bruce W. La comedia española del Siglo de Oro. Publisher with Elder Olson. Teoria de la comedia. Barcelona: Ariel, 1978.

Weimer, Christopher B. "Ana Caro's El Conde Partinuplés and Calderón's La vida es sueño: Protofeminism and Heuristic Imitation." Bulletin of the Comediantes 52.1 (2000): 123-46.

Williamsen, Amy. "Re-writing in the Margins: Ana Caro's Valor, agravio y mujer as Challenge to Dominant Discourse." Bulletin of the Comediantes 44.1 (1992): 21-30. 